\title{
The Relationship between Menstrual Disorder and Stres in Pandemic Covid-19 : A Literatur Review Analysis Situation in Primary Health Care From Indonesia
}

\author{
Titik Almujahidiani ${ }^{1}$, FikaMinata ${ }^{2}$, Penny Septiani ${ }^{3}$ \\ Faculty of Public Health, Universitas Kader Bangsa Palembang, South Sumatera, Indonesia ${ }^{1,3}$, \\ Faculty of Public Health, Universitas Indonesia, West Java, Indonesia ${ }^{2}$
}

\author{
Informasi Artikel : \\ Diterima : 24 September 2020 \\ Direvisi : 30 September 2020 \\ Disetujui : 10 Oktober 2020 \\ *Korespondensi Penulis : \\ titikalmujahidiani@gmail.com
}

\section{A B S T R A K}

Prevalensi angka kejadian Covid-19 di menurut WHO per tanggal 01 September 2020 sebanyak 25.118 .689 terinfeksi Covid-19 dengan kasus kematian sebanyak 844.312 dengan persentase 3,4\%. Data WHO pada tahun 2012 prevalensi gangguan menstruasi pada wanita yaitu $45 \%$. Dari hasil yang diperoleh jumlah yang terpapar covid-19 di Indonesia masih cukup tinggi sebasar 141.370 kasus dan urutan ke dua dari 10 negara ASEAN lainnya. Di negara Arab menunjukkan adanya hubungan yang signifikan antara tingkat stress dengan gangguan menstruasi. Kejadian gangguan menstruasi sebanyak 27\%. Penelitian lain di China melalui survei online hal ini menunjukkan gejala depresi sedang hingga berat sebanyak $16,5 \%$, memiliki gejala kecemasan sedang hingga berat sebanyak $28,8 \%$ dan dilaporkan mengalami tingkat stress sedang hingga berat sebanyak $8,1 \%$. Penelitian di Amerika dalam regulasi emosi secara signifikan memoderasi hubungan antara fase menstruasi dan control yang dirasakan atas kejadian terkait kecemasan $(B=-0,42$, $P<0,05)$. Penelitian lain di Afrika krisis covid-19 telah mengubah peningkatan risiko terjadinya dan keparahan gangguan menstruasi terkait stress. Penelitian ini diharapkan agar dapat memberikan pengetahuan mengenai penanganan psikologis yang dapat menyebebkan gangguan pada menstruasi selama masa covid-19.

\section{Kata Kunci : Gangguan menstruasi, covid-19}

\section{ABSTRACT}

The prevalence of the Covid-19 incidence according to WHO as of 01 September 2020 was 25,118,689 infected with Covid-19 with 844,312 cases of death with a percentage of $3.4 \%$. WHO data in 2012, the prevalence of menstrual disorders in women was $45 \%$. From the results obtained, the number of people exposed to Covid19 in Indonesia is still quite high, reaching 141,370 cases and second among 10 other ASEAN countries. In Arab countries, there is a significant relationship between stress levels and menstrual disorders. The incidence of menstrual disorders was 27\%. Another study in China through an online survey showed moderate to severe depression symptoms as much as $16.5 \%$, had moderate to severe symptoms of anxiety as much as $28.8 \%$ and reported experiencing moderate to severe stress levels as much as $8.1 \%$. The American study on emotion regulation significantly moderated the relationship between menstrual phases and perceived control for anxiety-related events $(B=-0.42, P<0.05)$. Other studies in Africa of the covid-19 crisis have altered the increased risk of developing and severity of stress-related menstrual disorders. This research is expected to be able to provide knowledge about psychological treatment that can cause menstrual disorders during the covid-19 period.

Keywords: Menstrual Disorders, Covid-19 


\section{PENDAHULUAN}

Pada akhir desember 2019 wabah Covid19 pertama kali muncul di Kota Wuhan, Provinsi Hubei. World Health Organization (WHO) menetapkan wabah COVID-19 menjadi ancaman terhadap kesehatan global yang disebabkan oleh Severe Acute Respiratory Syndrome Coronavirus-2 (SARS-CoV-2) ${ }^{1}$.Prevalensi angka kejadian per tanggal 01 September 2020 sebanyak 25.118.689 terinfeksi dengan kasus kematian sebanyak $844.312^{2}$. COVID-19 adalah virus corona beta yang menyebar di antara manusia setelah interaksi fisik yang erat.Gejalanya meliputi menggigil, batuk, coryza, sakit tenggorokan, kesulitan bernapas, mialgia, mual, muntahdan diare, tetapi tidak ada tanda patognomonik yang menyertai penyakit ${ }^{3}$.

Sejak pandemi Covid-19 kehidupan masyarakat menjadi tidak normal ditambah dengan perlindungan yang tidak memadai, kerja berlebihan, frustrasi, diskriminasi, isolasi, pasien dengan emosinegatif, kurangnya kontak dengan keluarga dan kelelahan ${ }^{4}$. Situasi saat ini menyebabkan masalah kesehatan mental sepertistres, kecemasan, gejala depresi, insomnia, penyangkalan, kemarahan dan ketakutan ${ }^{5}$. Isolasi sosial yang dilakukan selama pandemik ini berdampak secara psikis terhadap wanita sehingga mempengaruhi secara tidak langsung siklus menstruasi sehingga siklus menstruasi terganggu ${ }^{6}$.

Prevalensi gangguan menstruasi menurut WHO pada tahun 2012 pada wanita sebesar $45 \%$, sedangkan data prevalensi untuk negara di Indonesia sebesar $13,7 \%$ disebabkan fungsi hormon, kelainan sistemik, stres, kelenjar gondok, dan hormon prolaktin yang berlebihan ${ }^{7}$. Data Sumater Selatan menyebutkan untuk ganguan menstruasisebesar $11,7 \%$ dan menduduki peringkat 24 dari 34provinsi yang ada di Indonesia untuk kasus tertinggi gangguan menstruasi ${ }^{8}$.Gangguan menstruasi adalah kondisi dimana ketika siklus menstruasi mengalami anomali atau kelainan ${ }^{9}$. Hal ini disebabkan oleh pendarahan menstruasi yang terlalu banyak atau terlalu sedikit, siklus menstruasi yang tidak beraturan dan bahkan tidak haid sama sekali. Setiap wanita memiliki siklus menstruasi yang berbeda-beda.

Siklus menstruasi normal biasanya terjadi selama 3-7 hari dan berulang setiap 28 sampai 30 hari sekali setiap bulannya ${ }^{9}$. Etiologi dari menstruasiadalah gaya hidup, ketidakseimbangan hormon dan kelainan anatomi. Fisiologi pada siklus menstruasi ada 4 fase yaitu fase falikuler/proliferasi, fase luteal/ fase sekresi, fase menstruasi dan fase regenerasi/ pasca menstruasi ${ }^{10}$. Adapun faktor-faktor yang mempengaruhi gangguan menstruasi seperti pengetahuan, berat badan, aktifitas fisik, stres, paparan lingkungan, genetik, ras, umur, status gizi dan konsumsi obat tertentu ${ }^{11}$. Masalah gangguan menstruasi ini menjadi masalah yang diperhatikan oleh pemerintah.

Upaya yang dilakukan pemerintah Indonesiaberdasarkan Peraturan Pemerintah Republik Indonesia Nomor 61 Tahun 2014 tentang kesehatan reproduksi dalam pasal 11 dijelaskan bahwa pemerintah menerapkan pelayanan kesehatan reproduksi remaja yang bertujuan untuk mempersiapkan remaja agar menjalani kehidupan reproduksi yang sehat dan bertanggung jawab. Selain itu tertuang pada Permenkes No.25 tahun 2014 tentang Upaya Pelayanan Kesehatan anak ${ }^{12}$. Hal ini bertujuan untuk meningkatkan kualitas pelayanan kesehatan peduli remaja (PKPP)dalam memberikan informasi kesehatan remaja dan pelayanan konseling disemua tempat pelayanan.

Pada saat menstruasi pertama, kebanyakan remaja mengalami kepanikan dan Sebagian besar dari para remaja tidak tau cara menghadapi kepanikan tersebut. Pada saat Covid-19 ini banyak remaja yang mengalami stress akibat dari penerapan belajar dirumah karena harus menjaga jarak. Hal demikian juga dapat membuat terganggunya siklus menstruasi karena pola hidup berubah. Misalnya aktivitas yang membuat para remaja bermalas-malasan (sedentary-life) dan lebih banyak jajan sembarangan (ngemil) yang lebih banyak mengandung MSG. MSG adalah monosodium glutamate yang dapat meningkatkan gangguan menstruasi.

\section{Hasil}

\begin{tabular}{|c|c|c|c|c|c|c|}
\hline & $\begin{array}{l}\text { Total } \\
\text { Cases }\end{array}$ & $\begin{array}{l}\text { New } \\
\text { Cases }\end{array}$ & $\begin{array}{c}\text { Total } \\
\text { Deaths }\end{array}$ & $\begin{array}{c}\text { New } \\
\text { Deaths }\end{array}$ & $\begin{array}{c}\text { Total } \\
\text { Recovered }\end{array}$ & $\begin{array}{l}\text { Active } \\
\text { Cases }\end{array}$ \\
\hline Indonesia & 84,882 & $+1,752$ & 4,016 & +59 & 43,268 & 37,598 \\
\hline Philippines $>$ & 65,304 & $+2,357$ & 1,773 & +113 & 22,067 & 41,464 \\
\hline Singapore & 47,655 & +202 & 27 & 0 & 43,577 & 4,051 \\
\hline 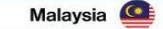 & 8,764 & +9 & 122 & 0 & 8,546 & 96 \\
\hline Thailand $\rightleftharpoons$ & 3,246 & +7 & 58 & o & 3,096 & 92 \\
\hline Vietnam $\Theta$ & 382 & +1 & o & 0 & 357 & 25 \\
\hline Myanmar & 339 & 0 & 6 & 0 & 271 & 62 \\
\hline Cambodia 4 & 171 & 0 & 0 & 0 & 133 & 38 \\
\hline Brunei & 141 & 0 & 3 & 0 & 138 & 0 \\
\hline Lao PDR 0 & 19 & 0 & 0 & 0 & 19 & 0 \\
\hline ASEAN 8 & 210,903 & $+4,328$ & 6,005 & +172 & 121,472 & 83,426 \\
\hline
\end{tabular}


Dari data ASEAN hasil yang diperoleh jumlah yang terpapar Covid-19 di Indonesia masih cukup tinggi sebasar 43.268 kasus dan urutan pertama dari 10 negara ASEAN lainnya ${ }^{5}$. Menurut dr. lahargo, Sp.KJ berdasarkan Survei yang dilakukan di laman resmi Perhimpunan Dokter Spesialis Kedokteran Jiwa Indonesia sebanyak $64,3 \%$ dari 1.522 orang responden memiliki masalah psikologis atau depresi setelah melakukan periksa mandiri melalui daring terkait kesehatan jiwa dampak dari pandemi Covid-19 dan apabila tidak ditangani dengan baik akan berdampak pada tingkat stres yang lebih tinggi ${ }^{13}$.

Gejala cemas, depresi dan stres berupa rasa takut dan khawatir yang berlebihan, tidak bisa rileks, mengalami gangguan tidur dan kewaspadaan yang berlebihan. Dari respoden yang ada wanita yang paling banyak memiliki masalah psikologis sebesar $76,1 \%$ dengan usia minimal antara 14 sampai 71 tahun. Responden paling banyak berasal dari Jawa Barat sebesar $23,4 \%$, DKI Jakarta 16,9 \%, Jawa Tengah 15,5\% dan Jawa Timur $12,8 \%{ }^{13}$.

\begin{tabular}{|c|c|c|c|}
\hline NO & Judul Penelitian & Tahun & Hasil \\
\hline 1 & $\begin{array}{lrr}\text { Prevalence of } & \text { menstrual } \\
\text { problems and } & \text { their } \\
\text { association with psychological } \\
\text { stress in young female } \\
\text { students studying health } \\
\text { sciences }\end{array}$ & 2011 & $\begin{array}{l}\text { Ninety-one percent of the students were suffering from } \\
\text { some kind of menstrual problem. The different menstrual } \\
\text { problems reported, and their incidences included } \\
\text { irregular menstruation }(27 \%), \text { abnormal vaginal } \\
\text { bleeding (9.3\%), amenorrhea }(9.2 \%), \text { menorrhagia } \\
(3.4 \%), \text { dysmenorrhea }(89.7 \%), \text { and premenstrual } \\
\text { symptoms }(46.7 \%) \text {. High perceived stress (HPS) was } \\
\text { identified in } 39 \% \text { of the students. A significant positive } \\
\text { correlation was found between HPS and menstrual } \\
\text { problems. Students with HPS had } 4 \text { times, } 2 \text { times, and } \\
2.8 \text { times increased odds ratio for experiencing } \\
\text { amenorrhea, dysmenorrhea, and premenstrual syndrome } \\
\text { (p }\end{array}$ \\
\hline 2 & $\begin{array}{l}\text { Impact of the COVID-19 } \\
\text { Pandemic on Mental Health } \\
\text { and Quality of Life among } \\
\text { Local Residents in Liaoning } \\
\text { Province, China: A Cross- } \\
\text { Sectional Study }\end{array}$ & 2020 & $\begin{array}{l}\text { A total of } 263 \text { participants (106 males and } 157 \text { females) } \\
\text { completed the study. The mean age of the participants } \\
\text { was } 37.7 \pm 14.0 \text { years, and } 74.9 \% \text { had a high level of } \\
\text { education. The mean IES score in the participants was } \\
13.6 \pm 7.7 \text {, reflecting a mild stressful impact. Only } 7.6 \% \\
\text { of participants had an IES score } \geq 26 \text {. The majority of } \\
\text { participants }(53.3 \%) \text { did not feel helpless due to the } \\
\text { pandemic. On the other hand, } 52.1 \% \text { of participants felt } \\
\text { horrified and apprehensive due to the pandemic. } \\
\text { Additionally, the majority of participants (57.8-77.9\%) } \\
\text { received increased support from friends and family } \\
\text { members, increased shared feeling and caring with } \\
\text { family members and others. }\end{array}$ \\
\hline 3 & $\begin{array}{l}\text { The role of emotion regulation } \\
\text { in the experience of menstrual } \\
\text { symptoms and perceived } \\
\text { control of anxiety-related } \\
\text { events throughout the }\end{array}$ & 2016 & $\begin{array}{l}\text { In emotional regulation significantly moderate the } \\
\text { relationship between menstrual phases and perceived } \\
\text { control for anxiety-related events }(B=-0,42 p<0,05)\end{array}$ \\
\hline
\end{tabular}

Di negara Arab menunjukkan adanya hubungan yang signifikan antara tingkat stress dengan gangguan menstruasi kejadian gangguan menstruasi sebanyak $27 \%^{14}$. Penelitian lain di China melalui survei online hal ini menunjukkan gejala depresi sedang hingga berat sebanyak $16,5 \%$, memiliki gejala kecemasan sedang hingga berat sebanyak $28,8 \%$ dan dilaporkan mengalami tingkat stress sedang hingga berat sebanyak $8,1 \%{ }^{2}$. Penelitian di Amerika dalam regulasi emosi secara signifikan memoderasi hubungan antara fase menstruasi dan control yang dirasakan atas kejadian terkait kecemasan $(B=-0,42$, $P<0,05)^{15}$. Penelitian lain di Afrika krisis covid19 telah mengubah peningkatan risiko terjadinya dan keparahan gangguan menstruasi terkait stress 16

Selanjutnya dapat di lihat beberapa perbedaan hasil penelitian tentang gangguan menstruasi di Indonesia dan negara berkembang lainnya di bawah ini : 


\begin{tabular}{|l|l|l|l|}
\hline & menstrual cycle & \\
\hline 4 & $\begin{array}{l}\text { Why Menstrual Health and } 2020 \\
\text { Wellbeing Promotion should } \\
\text { not be Sidelined in Africa's } \\
\text { Response to COVID-19 }\end{array}$ & $\begin{array}{l}\text { Prevalence of medical negligence and error, morbidity } \\
\text { and mortality; and development lag in the continent. } \\
\text { Prevention of these possible negative outcomes is only } \\
\text { feasible through continued and reinforced menstrual } \\
\text { health and wellbeing promotion facilitated by the African } \\
\text { government and other stakeholders. }\end{array}$ \\
\hline
\end{tabular}

\section{Kesimpulan}

Pembatasan Sosial Berskala Besar (PSBB) saat ini sudah diterapkan beberapa wilayah di Indonesia sebagai bagian dari upaya pencegahan penularan Covid-19. Pembatasan nasional yang dilakukan oleh pemerintah berupa lockdown, tidak berkumpul ditempat ramai dan standar pencegahan Covid-19. Akibat dari pandemi Covid-19 berdampak yang signifikan terhadap psikologis seseorang yang berpengaruh terhadap stress. Akibat dari stress yang dialami masyarakat berdampak adanya gangguan menstruasi pada wanita.

Kesejahteraan psikologis adalah kunci keberhasilan dalam menghadapi Covid-19 dan mencegah gangguan mental serta mengatasi emosi artinya individu harus mempersiapkan diri secara psikologis dan merasa aman dalam menghadapi kemungkinan situasi merugikan yang mungkin masih muncul saat ini. Diharapkan dengan kesejahteraan psikologis tercapai para wanita tidak mengalami gangguan menstruasi akibat dari stress yang di sebabkan dari pandemi Covid-19 ini.

Selama masa pandemi covid-19 yang mengharuskan sebagian besar melakukan aktivitas dirumah dan adanya pembatasan sekala besar mengenai social distancing dan physical distancing maka dari itu untuk mengurangi rasa bosan yang berujung ke stres, hal yang dapat dilakukan yaitu dengan memanfaatkan waktu luang sebanyak-banyaknya dengan menikmati dan enjoy pada keadaan apapun. Hal-hal yang bisa dilakukan yaitu meningkatkan kreatifitas yang dimiliki, mengisi waktu luang dengan bermain bersama keluarga, memasak, dan lain sebagainya.

\section{DAFTAR PUSTAKA}

1. H. Zheng, J. Tan, K. Ma, and W. Meng, "Changes in RT-PCR test results and symptoms during the menstrual cycle of female individuals infected with SARSCoV-2: Report of two cases," J. Med. Virol., no. July, pp. 1-5, 2020, doi: 10.1002/jmv.26275.

2. Y. Zhang and Z. F. Ma, "Impact of the COVID-19 pandemic on mental health and quality of life among local residents in Liaoning Province, China: A cross-sectional study," Int. J. Environ. Res. Public Health, vol. 17, no. 7, 2020, doi: 10.3390/ijerph17072381.

3. F. Durankuş and E. Aksu, "Effects of the COVID-19 pandemic on anxiety and depressive symptoms in pregnant women: a preliminary study," J. Matern. Neonatal Med., vol. 0, no. 0, pp. 1-7, 2020, doi: 10.1080/14767058.2020.1763946.

4. G. M. De Oliveira and D. Rossi, "COVID19 , Social Isolation and Human Stress Comparative Behavior \& Welfare," no. May, 2020, doi: 10.7537/marsnys130520.03.

5. J. Torales, M. O'Higgins, J. M. CastaldelliMaia, and A. Ventriglio, "The outbreak of COVID-19 coronavirus and its impact on global mental health," Int. J. Soc. Psychiatry, vol. 66, no. 4, pp. 317-320, 2020, doi: 10.1177/0020764020915212.

6. I. Sosial and M. Perilaku, "COVID-19, Isolasi Sosial dan Perilaku \& Kesejahteraan Komparatif Stres Manusia,” 2020.

7. C. Paspariny, "Tingkat Stres Mempengaruhi Gangguan Siklus Menstruasi," J. Ilm. Kesehat., vol. 1, no. 1, pp. 79-82, 2017, doi: 10.35952/jik.v6i2.97.

8. Riskesdas, "Riset Kesehatan Dasar Tahun2010," Riskesdas 2010, pp. 1-446, 2010, doi: 1 Desember 2013.

9. N. Karout, S. M. Hawai, and S. Altuwaijri, "Prevalence and pattern of menstrual disorders among Lebanese nursing students," East. Mediterr. Heal. J., vol. 18, no. 4, pp. 346-352, 2012, doi: 10.26719/2012.18.4.346. 
10. B.-P. Patricio and B.-G. Sergio, "Normal Menstrual Cycle," Menstrual Cycle, 2019, doi: 10.5772/intechopen.79876.

11. E. Ansong, S. K. Arhin, Y. Cai, X. Xu, and $\mathrm{X}$. Wu, "Menstrual characteristics, disorders and associated risk factors among female international students in Zhejiang Province, China: A cross-sectional survey," BMC Womens. Health, vol. 19, no. 1, pp. 1-10, 2019, doi: 10.1186/s12905-019-0730-5.

12. Direktur Jenderal Kesehatan Masyarakat, "Peran Rumah Sakit Dalam Menurunkan AKI dan AKB," pp. 1-27, 2018.

13. I. P. Association, "Panduan Penatalaksanaan Untuk Psikiater Yang Bertugas Di Layanan Kesehatan Jiwa Di Era Epidemi Covid-19," no. 010, 2020.

14. N. Rafique and M. H. Al-Sheikh, "Prevalence of menstrual problems and their association with psychological stress in young female students studying health sciences," Saudi Med. J., vol. 39, no. 1, pp. 67-73, 2018, doi: 10.15537/smj.2018.1.21438.

15. M. J. S. Benjamin M. Davis, Glen F. Rall, “乳鼠心肌提取 HHS Public Access,” Physiol. Behav., vol. 176, no. 1, pp. 139148, 2017, doi: 10.1016/j.physbeh.2017.03.040.

16. E. E. Ajari, "Why Menstrual Health and Wellbeing Promotion should not be Sidelined in Africa's Response to COVID19," Eur. J. Environ. Public Heal., vol. 4, no. 2, p. em0045, 2020, doi: 10.29333/ejeph/8278.

Abu Helwa, H. A., Mitaeb, A. A., Al-Hamshri, S., \& Sweileh, W. M. (2018). Prevalence of dysmenorrhea and predictors of its pain intensity among Palestinian female university students. BMC Women's Health, 18(1), $1-11$. https://doi.org/10.1186/s12905-018-0516-1

Ahmed, W. A. M., \& Mohammed, B. M. A. (2019). Nursing students' stress and coping strategies during clinical training in KSA. Journal of Taibah University Medical Sciences, $\quad 14(2), \quad 116-122$. https://doi.org/10.1016/j.jtumed.2019.02.00 2

Ajari, E. E. (2020). Why Menstrual Health and Wellbeing Promotion should not be Sidelined in Africa's Response to COVID19. European Journal of Environment and Public Health, 4(2), em0045. https://doi.org/10.29333/ejeph/8278

Ansong, E., Arhin, S. K., Cai, Y., Xu, X., \& Wu, $X$. (2019). Menstrual characteristics, disorders and associated risk factors among female international students in Zhejiang Province, China: A cross-sectional survey. BMC Women's Health, 19(1), 1-10. https://doi.org/10.1186/s12905-019-0730-5

Association, A. P. (2020). Stress in America ${ }^{\mathrm{TM}}$ 2020: Stress in the Time of COVID-19, Volume One. Https://Www.Apa.Org, May, 2019-2021.

https://www.apa.org/news/press/releases/str ess/2020/report\%0Ahttp://files/461/report.ht $\mathrm{ml}$

Bae, J., Park, S., \& Kwon, J. W. (2018). Factors associated with menstrual cycle irregularity and menopause. BMC Women's Health, 18(1), $1-11$. https://doi.org/10.1186/s12905-018-0528-x

Benjamin M. Davis, Glen F. Rall, M. J. S. (2017 HHS Public Access. Physiology \& Behavior, 176(1), 139-148. https://doi.org/10.1016/j.physbeh.2017.03.0 40

Bromberger, J. T., Schott, L. L., Matthews, K. A., Kravitz, H. M., Randolph, J. F., Harlow, S., Crawford, S., Green, R., \& Joffe, H. (2012). Association of past and recent major depression and menstrual characteristics in midlife: Study of Women's Health Across the Nation. Menopause, 19(9), 959-966. https://doi.org/10.1097/gme.0b013e318248f 2d5

del Mar Fernández, M., Regueira-Méndez, C., \& Takkouche, B. (2019). Psychological factors and premenstrual syndrome: A Spanish case-control study. PLOS ONE, 14(3), 1-13. https://doi.org/10.1371/journal.pone.021255 7

Diaz, A., Laufer, M. R., \& Breech, L. L. (2006). Menstruation in girls and adolescents: Using the menstrual cycle as a vital sign. Pediatrics, 118(5), 2245-2250. https://doi.org/10.1542/peds.2006-2481

Durankuş, F., \& Aksu, E. (2020). Effects of the COVID-19 pandemic on anxiety and depressive symptoms in pregnant women: a 
Jurnal Kebidanan :Jurnal Medical Science Ilmu Kesehatan Akademi Kebidanan Budi Mulia Palembang Volume.10 No.2, Desember 2020

preliminary study. Journal of Maternal-

Fetal and Neonatal Medicine, 0(0), 1-7. https://doi.org/10.1080/14767058.2020.176 3946

Ekpenyong, C. E., Davis, K. J., Akpan, U. P., \& Daniel, N. E. (2011). Academic stress and menstrual disorders among female undergraduates in Uyo, South Eastern Nigeria - The need for health education. Nigerian Journal of Physiological Sciences, 26(2), 193-198.

Eleanor, T., \& Gilbrech, K. I. (2020). ScholarWorks@UARKThe Impact of Stress on the Menstrual Cycle The Impact of Stress on the Menstrual Cycle.

Etim, N. N.; Offiiong, E. E. A.; Udo, M. D.; Williams, M. E.; Evans, E. I. (2013). Physiological relationship between stress and reproductive efficiency. Agriculture, and Biology Journal of North America, 4(6), 600-604. https://doi.org/10.5251/abjna.2013.4.6.600. 604

Faramarzi, M., Pasha, H., Bakhtiari, A., Salmalian, H., Delavar, M. A., Amiri, F. N., \& Nikpour, M. (2013). Test anxiety in objective structured clinical examinations (OSCEs) compared with traditional assessment methods in undergraduate midwifery students. Health, 05(12), 2204 2209.

https://doi.org/10.4236/health.2013.512299

Gustina, E., \& Djannah, S. N. (2015). Sumber Informasi Dan Pengetahuan Tentang Menstrual Hygiene Pada Remaja Putri. Jurnal Kesehatan Masyarakat, 10(2), 147. https://doi.org/10.15294/kemas.v10i2.3375

Indonesia masih catatkan angka kematian covid19 tertinggi di ASIA Tenggara (http://covid19.kemenkes.go.id/category/situasi-infeksiemerging/info- corona-virus/) di akses 01 September 2020

Kabbara, R., Ziade, F., \& Gannagé-Yared, M. H. (2014). Prevalence and etiology of menstrual disorders in Lebanese university students. International Journal of Gynecology and Obstetrics, 126(2), 177178. https://doi.org/10.1016/j.ijgo.2014.01.010

Maner, J. K., \& Miller, S. L. (2014). Hormones and social monitoring: Menstrual cycle shifts in progesterone underlie women's sensitivity to social information. Evolution and Human Behavior, 35(1), 9-16. https://doi.org/10.1016/j.evolhumbehav.201 3.09.001
Márquez, S., \& Molinero, O. (2013). Disponibilidad De energía, disfunción menstrual y salud ósea en el deporte; una revisión de la tríada de la atleta femenina. Nutricion Hospitalaria, 28(4), 1010-1017. https://doi.org/10.3305/nh.2013.28.4.6542

McEwen, Bruce S, Eiland, Lisa, Hunter, Richard G, Miller, M. M. (2012). Regulation As a Consequence of Stress.

Neuropharmacology, 62(1), 3-12. https://doi.org/10.1016/j.neuropharm.2011.0 7.014.Stress

Mohebbi, M., Amir Ali Akbari, S., Mahmodi, Z., \& Nasiri, M. (2017). Comparison between the lifestyles of university students with and without premenstrual syndromes. Electronic Physician, 9(6), 4489-4496. https://doi.org/10.19082/4489

Mustafa, N. (2020). Psychological Stress and Associated Factors during the Coronavirus Disease ( COVID-19). 24969. https://doi.org/10.13140/RG.2.2.21652.249 69

Nillni, Y. I., Wesselink, A. K., Hatch, E. E., Mikkelsen, E. M., Gradus, J. L., Rothman, K. J., \& Wise, L. A. (2018). Mental health, psychotropic medication use, and menstrual cycle characteristics. Clinical Epidemiology, 10, 1073-1082. https://doi.org/10.2147/CLEP.S152131

Oliveira, G. M. De, \& Rossi, D. (2020). COVID19 , Social Isolation and Human Stress Comparative Behavior \& Welfare. May. https://doi.org/10.7537/marsnys 130520.03

Ozamiz-etxebarria, N. (2020). Tingkat stres, kecemasan, dan depresi pada tahap awal wabah COVID-19 dalam sampel populasi di Spanyol utara Semua yang Anda butuhkan, lalu klik untuk melihat fase pertama lakukan pada COVID-19 em di bawah amostra no norte da Espanha. 36(4).

Ozamiz-Etxebarria, N., Dosil-Santamaria, M., Picaza-Gorrochategui, M., \& IdoiagaMondragon, N. (2020). Stress, anxiety, and depression levels in the initial stage of the COVID-19 outbreak in a population sample in the northern Spain. Cadernos de Saude Publica, 36(4), 1-9. https://doi.org/10.1590/0102311 X00054020

Rafique, N., \& Al-Sheikh, M. H. (2018). Prevalence of menstrual problems and their association with psychological stress in young female students studying health sciences. Saudi Medical Journal, 39(1), 67- 
73. https://doi.org/10.15537/smj.2018.1.21438

Rathi, A. K., Agrawal, M., \& Baniya, G. C. (2019). A study of impact of stress: examinations on menstrual cycle among medical students. International Journal of Research in Medical Sciences, 7(12), 4703. https://doi.org/10.18203/23206012.ijrms20195542

Schliep, K. C., Mumford, S. L., Vladutiu, C. J., Ahrens, K. A., Perkins, N. J., Sjaarda, L. A., Kissell, K. A., Prasad, A., WactawskiWende, J., \& Schisterman, E. F. (2015). Perceived stress, reproductive hormones, and ovulatory function: a prospective cohort study. Epidemiology (Cambridge, Mass.), 26(2), 177-184.

https://doi.org/10.1097/EDE.000000000000 0238

Sommer, M., Phillips-Howard, P. A., Mahon, T., Zients, S., Jones, M., \& Caruso, B. A. (2017). Beyond menstrual hygiene:

Addressing vaginal bleeding throughout the life course in low and middle-income countries. BMJ Global Health, 2(2), 1-6. https://doi.org/10.1136/bmjgh-2017-000405

Sosial, I., \& Perilaku, M. (2020). COVID-19, Isolasi Sosial dan Perilaku \& Kesejahteraan Komparatif Stres Manusia.

Torales, J., O’Higgins, M., Castaldelli-Maia, J. M., \& Ventriglio, A. (2020). The outbreak of COVID-19 coronavirus and its impact on global mental health. International Journal of Social Psychiatry, 66(4), 317-320. https://doi.org/10.1177/0020764020915212

Torales, J., O’Higgins, M., Castaldelli-Maia, J. M., \& Ventriglio, A. (2020). The outbreak of COVID-19 coronavirus and its impact on global mental health. International Journal of Social Psychiatry, 66(4), 317-320. https://doi.org/10.1177/0020764020915212

Vakilian, K., Gholami, R., Ghare-shiran, S. Y., \& Rahmani, A. (2016). Nursing and Health Care Menstrual Disorders in the Case of Students of University of Medical ClinMed. $2(5)$.

Watanabe, K., \& Shirakawa, T. (2015). Characteristics of Perceived Stress and Salivary Levels of Secretory Immunoglobulin A and Cortisol in Japanese Women With Premenstrual Syndrome. Nursing and Midwifery Studies, 4(2). https://doi.org/10.17795/nmsjournal24795

Wood, W., Kressel, L., Joshi, P. D., \& Louie, B. (2014). Meta-analysis of menstrual cycle effects on women's mate preferences.
Emotion Review, 6(3), 229-249. https://doi.org/10.1177/1754073914523073 Zhang, Y., \& Ma, Z. F. (2020). Impact of the COVID-19 pandemic on mental health and quality of life among local residents in Liaoning Province, China: A cross-sectional study. International Journal of Environmental Research and Public Health, 17(7). https://doi.org/10.3390/ijerph17072381 
